\title{
P289: Prevalence and risk factors of hepatitis c virus infection in chronic hemodialysis patients at the university teaching hospital of point $\mathrm{g}$, Bamako, Mali
}

\author{
M Baby ${ }^{1 *}$, S Fongoro², MK Konaté1,2, A Diarra ${ }^{1}$, B Kouriba ${ }^{1}$, MK Maïga $^{2}$ \\ From 2nd International Conference on Prevention and Infection Control (ICPIC 2013) \\ Geneva, Switzerland. 25-28 June 2013
}

\section{Objectives}

The objective of this prospective study conducted in November 2008, was to determine the prevalence and the factors associated with Hepatitis C Virus (HCV) infection in chronic hemodialysis patients.

\section{Methods}

The study was carried out in the hemodialysis unit of the university teaching hospital of Point G. Serum samples were tested for anti-HCV antibody, anti-HIV antibody and HBs Ag using enzyme immunoassay methods (ELISA) at the laboratory of immunology of the National Blood Transfusion Service of Bamako. The following parameters were assessed: initial nephropathy, duration of the dialysis, history of blood transfusion, number of blood units transfused since the beginning of the dialysis, history of nosocomial exposure.

\section{Results}

A total of 66 patients were enrolled. The mean age of the patients was $42,27 \pm 14,8$ years, with a male to female sexratio of 1,44 . Anti-HCV antibodies were found in 13 chronic hemodialysis patients, leading to a prevalence of $19,7 \%$. A significant association was found between the bearing of $\mathrm{HCV}$ and the duration of the dialysis.

\section{Conclusion}

These results indicate that hepatitis $C$ is frequent in the chronic hemodialysis patients of the university teaching hospital of Point G, and that the duration of dialysis

${ }^{1}$ National Center for Blood Transfusion, University Hospital of Point G, Bamako, Mali

Full list of author information is available at the end of the article constitutes the main factor associated with the contamination by the $\mathrm{HCV}$.

\section{Competing interests}

None declared.

\section{Author details}

${ }^{1}$ National Center for Blood Transfusion, University Hospital of Point G, Bamako, Mali. ${ }^{2}$ Department of Nephrology, University Hospital of Point G, Bamako, Mali.

Published: 20 June 2013

doi:10.1186/2047-2994-2-S1-P289

Cite this article as: Baby et al:: P289: Prevalence and risk factors of hepatitis $\mathrm{C}$ virus infection in chronic hemodialysis patients at the university teaching hospital of point g, Bamako, Mali. Antimicrobial Resistance and Infection Control 2013 2(Suppl 1):P289.

\section{Submit your next manuscript to BioMed Central and take full advantage of: \\ - Convenient online submission \\ - Thorough peer review \\ - No space constraints or color figure charges \\ - Immediate publication on acceptance \\ - Inclusion in PubMed, CAS, Scopus and Google Scholar \\ - Research which is freely available for redistribution

